\title{
MENINGKATKAN KEMAMPUAN SISWA PADA PEMBELAJARAN OPERASI HITUNG PENJUMLAHAN DAN PENGURANGAN BILANGAN BULAT MELALUI MEDIA KARTU BILANGAN PADA KELAS V DI SDN 24 TEMMALEBBA KEC. BARA KOTA PALOPO
}

\author{
Juli Pratama Saputri \\ Institut Agama Islam Negeri Palopo \\ Jl. Agatis Balandai, Kota Palopo \\ E-mail: juliprasaputri@gmail.com
}

\begin{abstract}
The study aims to 1) Knowing whether the use of number card media can inprove students' ability on the subject matter of counting and reducting analysis of 5th grade integers at SDN 24 Temmalebba. 2) To know the improvement of students' ability on material count arithmetic operation and reduction of integer through media of number card in class V/A at SDN 24 Temmalebba. This research is a classroom action research conducted in class V/A. Data collection tecnique which in conducted observation method, documentation, interview and test. Data analysis conducted in this research is decriptive analysis that is data reduction, data presentation and conclusion. The results of this research indicate that: 1) By using the number card media, the students' ability on the learning of the counting operation of the sum and reduction of the integers of grade students can increase. 2) Improvement of students' ability test result on learning of sum and integer counting operation every cycle has increased, it can be seen from the average of student's learning result that is less categorized prasiklus less that average value equal to 52 or klasikal equal to 14,29\%, in te first cycle is categorized enough from the average value of 62,3 or by classically $42,86 \%$ and on cycle 2 is categorized very well from the average value of 83 or by classical 88,57\%. Therefore the number card media need to be used as a reference by the teacher in the activity of calculating the operation of counting and the reduction of integers in primary school.
\end{abstract}

Keywords: Article, Contents, Format

\begin{abstract}
Abstrak
Penelitian ini bertujuan untuk: 1) Mengetahui apakah penggunaan media kartu bilangan dapat meningkatkan kemampuan siswa pada materi operasi hitung penjumlahan dan pengurangan bilangan bulat kelas V/A di SDN 24 Temmalebba. 2) Mengetahui peningkatan kemampuan siswa pada materi operasi hitung penjumlahan dan pengurangan bilangan bulat melalui media kartu bilangan pada siswa kelas V/A di SDN 24 Temmalebba. Penelitian ini merupakan Penelitian Tindakan Kelas (PTK) yang dilakukan di kelas V/A. Teknik pengumpulan data yang dilakukan melalui metode observasi, dokumentasi, wawancara dan tes. Analisis data yang dilakukan dalam penelitian ini secara analisis deskriptif yaitu reduksi data, penyajian data, dan penarikan kesimpulan. Hasil penelitian menunjukkan bahwa: 1) Dengan menggunakan media kartu bilangan, kemampuan siswa pada pembelajaran operasi hitung penjumlahan dan pengurangan bilangan bulat siswa kelas V/A dapat meningkat; 2) Peningkatan hasil tes kemampuan siswa pada pembelajaran operasi hitung penjumlahan dan pengurangan bilangan bulat pada setiap siklus mengalami peningkatan, hal ini dapat dilihat dari rata-rata hasil belajar siswa yaitu prasiklus dikategorikan kurang dari nilai rata-rata sebesar 52 atau klasikal sebesar 14,29\%, pada siklus I dikategorikan cukup dari nilai rata-rata 62,3 atau secara klasikal sebesar 42,86\% dan pada siklus II dikategorikan sangat baik dari
\end{abstract}


nilai rata-rata 83 atau secara klasikla sebesar 88,57\%. Dengan demikian media kartu bilangan perlu dijadikan referensi oleh guru dalam kegiatan pembelajaran operasi penjumlahan dan pengurangan bilangan bulat di sekolah dasar.

Kata Kunci,: Pembelajaran Matematika, Bilangan Bulat, Kartu Bilangan.

\section{PENDAHULUAN}

Mata pelajaran matematika diajarkan mulai dari jenjang Sekolah Dasar (SD) sampai perguruan tinggi (minimal sebagai mata kuliah umum). Karena dalam mata pelajaran matematika, siswa secara bertahap dapat mengembangkan kemampuan berfikir logis, analisis, sistematis, kritis dan kreatif. Beth dan Piaget yang dikutip J. Tombokan Runtukahu (2013:28)mengatakan bahwa "matematika adalah pengetahuan yang berkaitan dengan berbagai struktur abstrak dan hubungan antar-struktur terorganisasi dengan baik dan".

Kurikulum Tingkat Satuan Pendidikan (KTSP) matematika Sekolah Dasar, memiliki beberapa materi pelajaran yang terdapat dalam pelajaran matematika dan harus dipahami oleh siswa, salah satunya adalah materi operasi hitung penjumlahan dan pengurangan bilangan bulat. Operasi hitung bilangan bulat meliputi penjumlahan,pengurangan, perkalian, serta pembagian bilangan bulat. Di antara ke empat operasi hitung bilangan bulat tersebut peneliti hanya meneliti penjumlahan dan pengurangan bilangan bulat. Karena penjumlahan dan pengurangan bilangan bulat menjadi dasar untuk menghitung operasi bilangan bulat. Menurut Rey dkk, (2013:103) ada tiga syarat tiga syarat utama operasi bilangan yaitu keterampilan membilang, pengalaman konkret, kemampuan Bahasa.

Berdasarkan hasil observasi yang dilakukan peneliti di SD tersebut. Dari hasil observasi terungkap bahwa: Selama proses pembelajaran sebagian siswa pasif, hal ini disebabkan karena siswa tidak dilibatkan langsung sehingga kurangnya pemahaman siswa terhadap meteri operasi hitung penjumlahan dan pengurangan bilangan bulat. Dapat diketahui dari table kategori kemampuan awal siswa sebagai berikut: 5 siswa mendapat nilai termasuk kategori baik sekali, 17 siswa yang mendapat nilai termasuk kategori cukup, dan 13 siswa termasuk kategori gagal. Oleh karena itu, secara umum kemampuan siswa bisa dikatakan sangat rendah, karena baru ada 5 siswa atau $14,29 \%$ yang nilainya dapat memenuhi Kriteria Ketuntasan Minimal (KKM) yaitu 70.

Permasalahan ini harus diatasi agar kualitas pembelajaran di Sekolah Dasar (SD) yang dilakukan gurudapat meningkatkan pemahaman siswa. Salah satu media yang dapat digunakan guru adalah media kartu bilangan.

PiJIES: Pedagogik Journal of Islamic Elementary School 
Para siswa diberi kesempatan oleh guru untuk mempelajari dan memahami pembelajaran matematika pada materi operasi hitung penjumlahan dan pengurangan bilangan bulat.

Menurut Ruseffendi bahwa "matematika adalah bahasa simbol, ilmu deduktif yang tidak menerima pembuktian secara induktif, ilmu tentang pola keteraturan, dan struktur yang terorganisasi,mulai dari unsur yang tidak didefinisikan, ke unsur yang didefinisikan, ke aksioma atau postulat dan akhirnya ke dalil" (Heruman: 2008:1).Menurut Ahmad Susanto (2013:167) Pembelajaraan matematika adalah pengembangkan kreaktivitas berpikir siswa yang dibangun oleh guru dalam suatu proses belajar mengajar sebagai upaya meningkatkan penguasaan materi pelajaran matematika sehingga meningkatkan kemampuan mengkonstruksi pengetahuan.

Depdiknas (2003) dalam Prihandoko (2006:21) menyebutkan pada satuan Sekolah Dasar dan Madrasah Ibtidaiyah memiliki standar kompetensi untuk mata pelajaran matematika meliputi tiga aspek yaitu bilangan, pengukuran dan geometri serta pengolahan data. Pembelajaran matematika di Sekolah Dasar memiliki kompetensi atau kemampuan umum yang meliputi: Melakukan operasi hitung penjumlahan, pengurangan, perkalian, pembagian beserta operasi campurannya, termasuk yang melibatkan pecahan dan materi lainnya.Pada kurikulum matematika SD terdapat konsep konsepyaitu penanaman konsep dasar,pemahaman konsep, dan pembinaan keterampilan (Heruman 2008:3). Dalam pembelajaran matematika bagian yang sulit yaitu penanaman konsep, dibutuhkan teknik-teknik agar dapat menghubungkan kemampuan kognitif pada pola pikir siswa dengan konsep baru matematika.

Materi bilangan bulat sudah dikenal sejak pendidikan anak usia dini, mengenalkan berhitung dari 1, 2, 3, dan seterusnya. Tetapi belum pada operasi hitungnya. Pada dasarnya operasi hitung mencakup empat pengajaran dasar, yaitu: penjumlahan, pengurangan, perkalian, dan pembagian. Namun peneliti hanya akan membahas tentang penjumlahan dan pengurangan.

Bilangan bulat menurutYoppy Wahyu Purnomo(2013:201), merupakan bilangan cacah yang terdiri atas himpunan bilangan asli, yaitu $\{1,2,3,4, \ldots .$. disebut bilangan bulat positif, bilangan nol, dan $(-1,-2,-3,-4, \ldots$.$\} disebut$ himpunan bilangan bulat negatif.Bilangan bulatadalah "bilangan cacah beserta negatifnya atau lawannya" John A. Van De Walle (2008: 239). Sedangkan Sri Subarinah (2006:41), menyebutkan bahwa "himpunan bilangan bulat terdiri dari bilangan bulat negatif, bilangan bulat positif, dan bilangan nol". Maka dapat disimpulkan bahwa bilangan bulat negatif adalah 
bilangan yang lebih kecil atau kurang dari nol atau bisa juga dikatakan bilangan yang letaknya disebelah kiri angka nol. Bilangan nol yakni bilangan yang netral, bilangan nol disimbolkan 0. Sedangkan bilangan asli adalah bilangan yang terdiri atas bilangan bulat positif yang diawali dengan bilangan 1.Media pembelajaran adalah alat untukmemperjelas, membantu dan mengkongkritkan penyampaian pesan di dalam proses pembelajaran agar potensi peserta didik dapat berkembang dan materi pelajaran dapat tersampaikan. Menurut Arief S. Sadiman dkk, (2007:6) bahwa "media berasal dari bahasa Latin dan merupakan bentuk jamak dari kata medium yang secara harfiah berarti perantara atau pengantar. Nana Sudjana (2001:2 -3) mengungkapkan bahwa dalam proses pengajaran, penggunaan media dapat mempertinggi proses belajarpeserta didik. Menurut Sardiman (1994:20) peranan media dalam proses pembelajaran adalah: Dapat menghemat waktu belajar, memudahkan pemahaman. meningkatkan perhatian, aktivitas dan mempertinggi daya ingat peserta didik. Hal ini disebabkan penggunaan media membuat suasana pembelajaran menjadi menyenangkan. Dengan demikian gelombang otak meningkat dan selanjutnya berpengaruh terhadap kemudahan siswa menerima informasi dan mempertahankannya dalam jangka waktu yang lama (Rustan \& Bahru, 2018). Sedangkan menurut Azhar Arsyad (2007:19) media pembelajaran dapat memenuhi tiga fungsi utama yaitu memotivasi minat atau tindakan, menyajikan informasi, dan member intruksi apabila media itu digunakan untuk perorangan, kelompok, atau kelompok pendengar yang jumlahnya. Penggunaan media dapat membangkitkan kondisi psikologis yang positif sehingga siswa terstimulus dalam mengikuti proses pembelajaran sekalipun terasa sulit untuk melakukannya (Thaha \& Rustan, 2017). Dalam proses pembelajaran, mediadapat membantu kegiatan pembelajaran agar memperjelas bahan/materi dan dapat meningkatkan aktivitas belajar siswa. Ahmad Rohani (2004:24), menjelaskan ada 2 macam alat peraga yaitu alat peraga langsung merupakan alat peraga yang dapat secara langsung diperlihatkan bendanya kepada siswa. Sedangkan alat peraga tidak langsung diperlihatkan menggunakan benda-benda tiruan.

Dalam pembelajaran matematika penggunaan media sangat diperlukan seperti yang dijelaskan Ruseffendi (1992:141) mengatakan bahwaalat peraga merupkan alat untuk menerangkan, menjelaskan dan mewujudkan konsep matematika. Alat peraga digunakan agar konsep bisa dengan mudah dipahami oleh siswa dalam memecahkan masalah pada materi operasi hitung penjumlahan dan pengurangan bilangan bulat. Salah satu media yang dapat digunakan yaitukartu bilangan.

PiJIES: Pedagogik Journal of Islamic Elementary School 
Aisyah,dkk (2007:2.26) mengemukakan bahwa kartu bilangan merupakan media permainan yang terbuat dari kertas menggunkan warna mencolok yang berbentuk persegi dengan ukuran $10 \mathrm{~cm}$ x $10 \mathrm{~cm}$. Dalam pembelajaran matematika, salah satu media yang digunakan dalam proses belajar mengajar dengan pendekatan keterampilan salah satunya adalah penggunaan kartu bilangan. Sedangkan menurut Sudarman dkk (2012) kartu posinega adalah dua kumpulan potongan kartonberbeda warna, dimana satu kartu mewaliki kartu positif dan kartu lainnya mewakili karu negatif. Maka dapat disimpulkan bahwa media kartu bilangan adalah media yang digunakan dalam proses belajar mengajar yang terbuat dari 2 kertas d engan warna berbeda,bernilai bilangan negatif, nol, dan positif yang dapat memudahkan siswa memahami materi operasi hitung penjumlahan dan pengurangan bilangan bulat dan menciptakan proses pembelajaran yang efektif.

Penggunaan media kartu bilangan dalam mengoperasikan kartu bilangan pada proses pembelajaran, ditentukan beberapa yaitu: 1) Membuat kesepakatan untuk menetapkan kartu positif dan kartu negative, 2) Satu kartu hijau ditetapkan sebagai kartu positif (+1), sedangkan satu kartu kuning ditetapkan sebagai kartu negative (-1), 3) Mendefiniskan bilangan nol dengan banyaknya kartu yang jumlahnya satu pasang maupun lebih sampai tak terhingga.

Berdasarkan penjelasan di atas dengan penggunaan media kartu bilangan pemahaman siswa terhadap pembelajaran operasi hitung penjumlahan dan pengurangan bilangan bulat bisa meningkat, olehnya itu peneliti merancang sebuah penelitian yang berjudul "Meningkatkan Kemampuan Siswa Pada Pembelajaran Operasi Hitung Penjumlahan Dan Pengurangan Bilangan Bulat Melalui Media Kartu Bilangan Pada Kelas V Di SDN 24 Temmalebba Kec. Bara Kota Palopo".

\section{METODE}

Penelitian ini difokuskan pada aktivitas pembelajaran di dalam kelas dengan menggunakan penelitian tindakan kelas dengan menggunakan model yang diterapkan Kurt Lewin menggunakan langkah sebagai berikut perencanaan, pelaksanaan, observasi dan refleksi, (Wina Sanjaya, 2013:50). Dalam penelitian ini menggunakan jenis data untuk mendukung penelitian, diantaranya a) Data primer adalah data yang dikumpulkan peneliti sendiri dengan cara melakukan observasi dan wawancara dengan pihak sekolah khusunya guru kelas V. b) Data sekunder adalah data yang dikumpulkan oleh orang lain dalam hal ini guru kelas V berupa dokumen/arsip siswa. Subjek penelitian ini adalah siswa kelas V/A di SDN 24 Temmalebba yang berjumlah 
35 orang, yang terdiri dari 16 siswa perempuan dan 19 siswa laki-laki. Teknik yang digunakan untuk mengumpulkan data penelitian ini adalah teknik tes, observasi, wawancara dan dokumentasi. Terkumpulkannya data pada penelitian ini didapatkan pada pengelolaan data. Selanjutnya dianalisis secara kuantitatif dan kualitatif. Untuk analisis secara kuantitatif digunakan analisis deskriptifyaitu skor rata-rata dan persentase. Sedangkan analisis kualitatif dilakukan terhadap data yang diperoleh melalui observasi aktivitas siswa dan guru dalam pembelajaran operasi hitung penjumlahan dan pengurangan bilangan bulat dengan menggunakan media kartu bilangan dengan langka reduksi, penyajian data, dan penarikan kesimpulan. Analisis ini dihitung dengan menggunakan statistik sederhana menjumlahkan nilai siswa yang diperoleh dan dibagi dengan jumlah siswa kelas tersebut sehingga nilai rata-rata dapat diperoleh, kemudian hasil penelitian yang telah diperolehdiklasifikasikan ke dalam bentuk penskoran nilai siswa dengan menggunakan kriteria standar penilaian, seorang siswa dikatakan tuntas belajar jika telah mencapai nilai 70 dan tuntas secara klasikal jika 75\% siswa yang telah tuntas belajarnya.

\section{HASIL DAN PEMBAHASAN HASIL PENELITIAN}

Penggunaan media kartu bilangan dalam pembelajaran operasi hitung penjumlahan dan pengurangan bilangan bulat pada siswa kelas V SDN 24 Temmalebba yaitu:guru menjelaskan penggunaan media kartu bilangan dimana $-2+3=\ldots$. Guru mengambil 2 kartu berwarna kuning dan 3 kartu berwarna hijau kemudian dipasangkan $\square$ karena ada 1 kartu hijau yang tidak mempunyai pasangan maka hasilnya adalah +1 .

Dalam proses pembelajaran terdapat masih banyak siswa yang belum memahami materi operasi hitung penjumlahan dan pengurangan bilangan bulat sehingga kesulitan mengerjakan soal yang dijelaskan oleh guru. Untuk memudahkan guru memberikan contoh penggunaan media kartu bilangan dengan membuat permainan agar siswa lebih antusias. Selanjutnya Guru membimbing siswa dalam mengerjakan operasi hitung penjumlahan dan pengurangan bilangan bulat.

Penggunaan media kartu bilangan pada pembelajaran operasi hitung penjumlahan dan pengurangan bilangan bulat, aktivitas siswa semakin mengalami meningkat, yang dapat dilihat dari lembar observasi yang dilakukan, dan hasil belajar siswa mengalami peningkatan dapat dilihat dari dari hasil tes belajar siswa. Berdasarkan uraian tersebut, secara keseluruhan semua kriteria aktivitas guru dan siswa dan analisis tes hasil PiJIES: Pedagogik Journal of Islamic Elementary School 
belajar siswatelah memenuhi kriteria yang ditetapkan pada indikator kinerjadari siklus I ke siklus II mengalami peningkatan. Sehingga dapat dikatakan bahwa peningkatan kemampuan siswa pada pembelajaran operasi hitung penjumlahan dan pengurangan bilangan bulat dapat terjadi kare na penggunaan media kartu bilangan.

Hasil tes kemampuan siswa pada siklus I menunjukkan ada 10 siswa $(28,57 \%)$ diklasifikasikan sangat baik, 5 siswa $(14,29 \%)$ diklasifikasikan baik, 6 siswa $(17,14 \%)$ diklasifikasikan cukup, 6 siswa $(17,14 \%)$ diklasifikasilan kurang dan 8 siswa (22,86\%) diklasifikasikan gagal. Oleh karena itu, secara umum kemampuan siswa bisa dikatakan sangat rendah, karena baru ada 15 siswa (42,86\%) yang nilainya dapat memenuhi Kriteria Ketuntasan Minimal (KKM).

Hasil tes kemampuan siswa pada siklus II menunjukkan ada sebanyak 27 siswa $(77,14 \%)$ dapat diklasifikasikan sangat baik, 4 siswa $(11,43 \%)$ diklasifikasikan baik, dan 4 siswa (11,43\%) diklasifikasikan cukup. Oleh karena itu, secara umum kemampuan siswa bisa dikatakan sangat baik, karena ada 31 siswa (88,57\%) yang nilainya dapat memenuhi Kriteria Ketuntasan Minimal (KKM).

Adapun nilai tes evaluasi pada SDN 24 Temmalebba yang dilakukan peneliti setiap siklus yang menandakan kemampuan siswa pada pembelajaran operasi hitung penjumlahan dan pengurangan bilangan bulat meningkat mulai dari tahap pra siklus siswa yang tuntas sebesar 14,29\%, pada tahap siklus I siswa yang tuntas sebesar $42,86 \%$, dan pada tahap siklus II siswa yang tuntas sebesar 88,57\%.

Berikut perbandingan hasil pembelajaran tahap pra siklus, siklus I dan siklus II dapat dilihat pada diagramberikut ini:

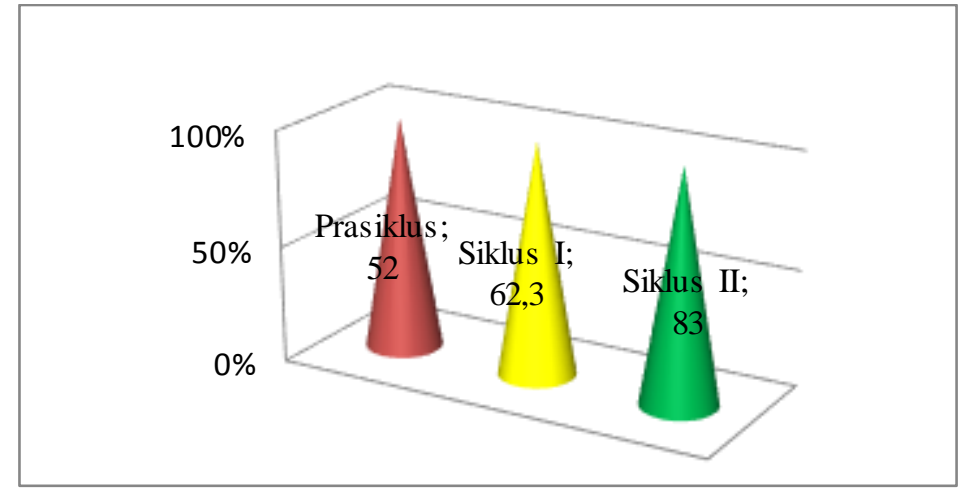

Diagram

Prasiklus, Siklus I, dan Siklus II 


\section{4 | Juli Pratama Saputri}

Maka, dengan menggunakan media kartu bilangan pada pembelajaran operasi hitung penjumlahan dan pengurangan bilangan bulat dapat meningkatkan kemampuan siswa kelas V/A SDN 24 Temmalebba Kota Palopo.

\section{PEMBAHASAN}

Pengajar dalam dunia pendidikan harus mampu membuat siswa kreatif dan inovatif dalam membentuk pola pikir siswa di dalam pembelajaran. Hal ini sesuai dengan kajian teori yang dikemukakan oleh (Rustan, 2010) yaitu "dalam konteks pendidikan multikultural yang berkarakter,pengajar harus mampu memberikan contoh-contoh pengaplikasian nilai dalam tingkah laku kesehariannya. Hal ini akan mengilhami siswa untuk membentuk karakternya sesuai dengan kompetensi yang diinginkannya".

Penelitian ini dilakukan sebagai upaya untuk meningkatkan kemampuan siswa pada pembelajaran operasi hitung penjmlahan dan pengurangan bilangan bulat, dimana siswa diharapkan lebih memperhatikan penjelasan guru dengan baik, siswa lebih antusias dalam belajar dan memberikan kemudahan dalam pembelajaran. Hal tersebut sesuai dengan kajian teori yang dikemukakan oleh Mansur Muslich (2011: 165) "lebih menekankan pada keterlibatan siswa secara aktif dalam memberikan pengalaman bermakna kepada siswa. Sehingga prestasi belajar siswa menjadi lebih optimal".

Untuk mencapai tujuan pembelajaran yang lebih optimal dibutuhkan pembelajaran yang menyenangkan bagi siswa agar pembelajaran lebih efektif. Pembelajaran yang menyenangkan menurut Suyatno dalam Yusuf (2011:9) yaitu "pembelajaran yang cocok dengan suasana yang terjadi dala m diri siswa". Apabila siswa tidak senang maka siswa akan pasif dan tidak tertarik mengikuti pembelajaran. Maka guru memerlukan kreativitas untuk membangun siswa dalam proses pembelajaran agar lebih bermutu.

Penggunaan media kartu bilangan yang memudahkan siswa memahami operasi hitung penjumlahan dan pengurangan bilangan bulat. Selain itu, siswa dapat mengasah pengetahuan dan membantu siswa dalam mengembangkan potensi-potensi yang dimilikinya. Dalam hal ini peluang keberhasilan belajar operasi hitung penjumlahan dan pengurangan bilangan bulat, tidak hanya dimiliki oleh siswa yang berkemampuan tinggi saja, tetapi juga siswa yang berkemampuan sedang bahkan siswa yang berkemampuan rendah juga dapat meraih keberhasilan. Sehingga dengan menggunakan media untuk memperoleh hasil pembelajaranyang optimal untuk memungkinkan keterlibatan siswa secara maksimal. Hal tersebut sesuai pendapat Susilana dan Riyana (2009:62) bahwa upaya untuk mewujudkan PiJIES: Pedagogik Journal of Islamic Elementary School 
pembelajaran tunjang oleh media yang sesuai dengan materi, stretegi yang digunakan, dan karakter siswa.

Hasil penelitian tindakan pada siklus I mencapai ketuntasan klasikal 42,86\% pencapaian ini belum memenuhi indikator kinerja yang ditetapkan. Pada tindakan siklus II ketuntasan belajar klasikal mencapai 88,57\%. Peningkatan skor perolehan pada siklus II telah membuktikan hipotesis tindakan. Hal ini sesuai dengan hasil penelitian yang dilakukan oleh Dian Kusniati yang dimuat oleh jurnal yang menjelaskan bahwa penelitian tetang penggunaan media kartu dapat dikatakan berhasil karena semua kriteria keberhasilan yang ditetapkan sudah tercapai pada siklus II.

Hasil penelitian menunjukkan bahwa masalah yang dihadapi siswa pada SDN 24 Temmalebba yaitu, siswa mengalami kesulitan dalam mengerjakan soaloperasi hitung penjumlahan dan pengurangan bilangan bulat dan masih banyak siswa yang belum mencapai kriteria ketuntasan minimal (KKM) dan guru belum menggunakan media yang tepat seperti media kartu bilangan untuk meningkatkan kemampuan siswa. Hal tersebut sesuai kajian teori yang dikemukakan oleh Wina Sanjaya, dkk (2004:99) bahwa "upaya bisa dilakukan dengan menjadikan siswa aktif mencari informasi dan pengetahuan yang diperlukan sehingga siswa tidak pasif, dan tidak hanya mendengarkan apa yang disampaikan oleh guru. Dengan kata lain, pembelajaran tidak lagi berpusat pada siswa".

\section{PENUTUP}

Hasil temuan dan pembahasan, maka hasil penelitian ini dapat disimpulkan bahwa;(1) Dengan menggunakan media kartu bilangan,kemampuan siswa pada pembelajaran operasi hitung penjumlahan dan pengurangan bilangan bulat siswa kelas V SDN 24 Temmalebba kota Palopo dapat meningkat; (2) Peningkatan hasil tes kemampuan siswa pada pembelajaran operasi hitung penjumlahan dan pengurangan bilangan bulat pada setiap siklus mengalami peningkatan, hal ini dapat dilihat dari rata-rata hasil belajar siswa yaitu prasiklus dikategorikan kurang dari nilai rata-rata sebesar 52 atau sebesar 14,29\%, pada siklus I, dikategorikan cukup dari nilai rata-rata 62,3 atau sebesar $42,86 \%$ dan pada siklus II, dan dikategorikan sangat baik dari nilai rata-rata 83 atau sebesar $88,57 \%$.

\section{DAFTAR PUSTAKA}

Aisyah,dkk.,2007. Pengembangan Pembelajaran Matematika SD.Jakarta: Departemen PendidikanNasional. 
Azhar, Arsyad.2007. Media Pembelajaran. Ed. Ke-1; Jakarta: PT. RajaGrafindo Persada.

Heruman, 2010. Model Pembelajaran Matematika di SD. Bandung: Remaja Rosdakarya.

Kusniati, Dian. Meningkatkan Hasil Belajar Siswa Kelas IV SDN 2 Patukuki Pada Pokok Bahasan Penjumlahan dan Pengurangan Bilangan Bulat Melalui Pembelajaran Menggunakan Media Kartu. Dapat diakses http://jurnal.untad.ac.id/jurnal/index.php/JKTO/article/view/2848

Muslich, Mansur. 2011.KTSP Pembelajaran dan Kontekstual. Jakarta: Bumi Aksara.

Purnomo, Yoppy Wahyu. 2013. Bilangan Cacah dan Bulat. Bandung: Alfabeta. Prihandoko, Antonius Cahya, 2006. Pemahaman Penyajian Konsep Matematika Secara Benar dan Menarik. Direktorat Jendral Pendidikan Tinggi Departemen Pendidikan Nasional.

Rohani, Ahmad. 2004. Pengelolahan Pengajaran. Jakarta: PT. Rineka Cipta.

Runtukahu, Tombokan dan Selpius Kandou.2014. Pembelajaran Matematika Dasar bagi anak berkesulitan belajar. Cet. 1; Yogyakarta: Ar-Ruzz Media.

Ruseffendi, 1992. Pendidikan Matematika 3. Jakarta: Departemen Pendidikan dan Kebudayaan Proyek Pembinaan Tenaga Kependidikan Pendidikan Tinggi.

Rustan, E. (2010). Kongres internasional. Prosiding Kongres International, 247.

Rustan, E., \& Bahru, M. S. (2018). Penguatan Self Confidence dalam Pembelajaran Matematika melalui Metode Suggestopedia. AlKhwarizmi: Jurnal Pendidikan Matematika Dan Ilmu Pengetahuan Alam, 6(1), 1-14.

Sadiman, Arief S. dkk,. 2007.Media Pendidikan; pengertian, pengembangan, dan pemanfaatannya.Ed. Ke-1; Jakarta: PT. RajaGrafindo Persada.

Sanjaya, Wina. 2009.Strategi Pembelajaran Proses Pendidikan. Jakarta: Kencana Pernada Media Group.

Sanjaya, Wina.2009. Penelitian Tindakan Kelas.Ed. Ke-1; Jakarta: Kencana Prenadamedia Group.

Sardiman, A.M. 1994. Interaksi dan Motivasi Belajar Mengajar.Bandung: Rajawali Press.

Subarinah, Sri. 2006. Inovasi Pembelajaran Matematika Sekolah Dasar. Departemen

Pendidikan Nasional Direktorat Jenderal Pendidikan Tinggi Direktorat Ketenagaan.

PiJIES: Pedagogik Journal of Islamic Elementary School 
Sudarman, Akina. 2012. Bilangan Bulat dan Pecahan. Pusbang-Prodik Bpsmpk-Pmp- KEMDIKBUD.

Sujana, Nana. 2001. Penelitian dan Penilaian Pendidikan. Bandung: Sinar Baru.

Susanto, Ahmad. 2013. Teori Belajar dan Pembelajaran di Sekolah Dasar. Ed. Ke-1; Jakarta: Kencana Prenadamedia Group.

Susilana dan Riyana. 2009. Media Pembelajaran: Hakikat, Pengembangan, Pemanfaatan dan Penilaian.Bandung: Wacana Prima.

Thaha, H., \& Rustan, E. (2017). Orientasi Religiusitas dan Efikasi Diri dalam Hubungannya dengan Kebermaknaan Pendidikan Agama Islam pada Mahasiswa IAIN Palopo. Studi Agama Dan Masyarakat, 13(2), 163-179. https://doi.org/10.23971/jsam.v13i2.551

Yusuf, Yasin dan Umi Auliya.2011. Sirkuit Pintar Melejitkan Kemampuan Matematika \& Bahasa Inggris dengan Metode Ular Tangga. Jakarta: Visi Media.

Van, John De Walles. 2000. Matematika SD dan menengah Pengembangan Pengajaran, Jakarta: Erlangga. 
138 | Juli Pratama Saputri

Halama Ini Sengaja Dikosongkan

PiJIES: Pedagogik Journal of Islamic Elementary School 